\title{
Hubungan antara Persepsi Situasi Pembelajaran dengan Pendekatan Belajar Mahasiswa Blok Muskuloskeletal di Fakultas Kedokteran Universitas Pelita Harapan
}

\author{
Rhendy Wijayanto*, Harsono**, Amitya Kumara*** \\ * Fakultas Kedokteran Universitas Pelita Harapan, Jakarta; ** Fakultas Kedokteran Universitas Gadjah Mada, \\ Yogyakarta; *** Fakultas Psikologi Universitas Gadjah Mada, Yogyakarta
}

\begin{abstract}
Background: Comprehension on student's learning approach is an essential issue because it deals with the learning quality. Student's perception on learning environment is a factor that influences student's learning appproach.

Objective: The aims of this study were to describe student's perception on learning environment, student's learning approach, relationship between student's perception on learning environment with learning approach applied in musculosceletal block at Faculty of Medicine Pelita Harapan University.

Method: This research was conducted using mixed method which combines two approaches type. A quantitative approach was the main approach, while qalitative approach acted as facilitatory approach. As many as 106 students of musculoscetal block participated as sample.

Result: Descriptive analysis showed that students perception was good on teaching quality (77.36\%), clear goals(59.43\%), and learning ability acquired (88.68\%). Meanwhile $68.87 \%$ of sample had unsatisfied perception on assessment and on workload (73.58\%). The correlation of learning environment perception to learning approach revealed $p$ value $>0.05$ which was not statistically significant. Qualitative findings showed the role of internal motivation in determining learning approah adopted by student. Internal motivation comprised interest in subject, previous knowledge, and selfesteem.

Conclusion: Student's perception of learning environment is not a predictor of learning approach applied by student in musculoscetal block. Internal motivation take part in determining students's learning approach.
\end{abstract}

Keywords: learning approach, learning environment, internal motivation

\begin{abstract}
Abstrak
Latar Belakang: Pemahaman terhadap kecenderungan pendekatan belajar mahasiswa merupakan hal penting karena berkaitan dengan kualitas pembelajaran yang diterapkan. Persepsi mahasiswa terhadap situasi pembelajaran merupakan faktor yang mempengaruhi kecenderungan pendekatan belajar yang diterapkan mahasiswa.

Tujuan: Tujuan dari penelitian ini adalah untuk mengetahui gambaran persepsi mahasiswa terhadap situasi pembelajaran, gambaran kecenderungan pendekatan belajar mahasiswa, serta peran persepsi situasi pembelajaran terhadap kecenderungan pendekatan belajar mahasiswa blok muskuloskeletal Fakultas Kedokteran Universitas Pelita Harapan.

Metode: Metode penelitian yang diterapkan adalah metode campuran (mixed method) yang mengkombinasikan dua pendekatan yaitu: pendekatan kuantitatif sebagai pendekatan utama, dan pendekatan kualitatif sebagai pendekatan fasilitator. Sampel penelitian ini adalah 106 mahasiswa blok muskuloskeletal FK UPH.

Hasil: Hasil analisis deskriptif menunjukkan terdapat persepsi yang baik terhadap kualitas pengajaran sebesar $77.36 \%$, tujuan belajar sebesar $59.43 \%$, dan kemampuan belajar yang diperoleh sebesar $88.68 \%$. Terdapat persepsi yang kurang baik terhadap kejelasan assessment sebesar $68.87 \%$ dan beban belajar sebesar $73.58 \%$. Korelasi persepsi situasi pembelajaran terhadap kecenderungan pendekatan belajar menunjukkan nilai $\mathrm{p}>0.05$ yang berarti tidak bermakna secara statistik. Hasil penelitian kualitatif menemukan adanya peranan motivasi internal dalam
\end{abstract}

Korespondensi: rhendyw@yahoo.com 
mempengaruhi kecenderungan pendekatan belajar yang diterapkan mahasiswa. Motivasi internal tersebut adalah ketertarikan terhadap materi, pengetahuan sebelumnya tentang tema yang dipelajari, dan self-esteem.

Kesimpulan: Persepsi mahasiswa terhadap situasi pembelajaran tidak dapat menjadi prediktor kecenderungan pendekatan belajar yang diterapkan mahasiswa di blok muskuloskeletal. Motivasi internal turut berperan dalam pendekatan belajar mahasiswa.

Kata Kunci: situasi pembelajaran, pendekatan belajar, motivasi internal

\section{PENDAHULUAN}

Learning approach yang diterapkan mahasiswa dalam melaksanakan pembelajaran dikenal dengan istilah pendekatan belajar. Secara garis besar, pendekatan belajar dapat dibagi menjadi pendekatan mendalam atau deep approach dan pendekatan dangkal atau surface approach. Biggs ${ }^{1}$ menyatakan bahwa pendekatan dangkal berkaitan dengan kuantitas tanpa kualitas, sedangkan pendekatan mendalam adalah tentang kualitas dan kuantitas.

Penerapan situasi pembelajaran yang mengarahkan pada pendekatan mendalam merupakan hal penting karena dikaitkan dengan kesuksesan jangka panjang dalam pendidikan kedokteran. ${ }^{2}$ Pendekatan belajar yang baik yang diterapkan mahasiswa kedokteran adalah pendekatan mendalam karena akan membantu mengembangkan kemampuan pemecahan masalah yang dibutuhkan sebagai dokter yang kompeten; namun bukti menunjukkan bahwa situasi pembelajaran justru mengarahkan ke arah yang kurang baik yakni pendekatan dangkal. ${ }^{3}$

Dari studi pendahuluan melalui diskusi dengan 20 orang mahasiswa di Fakultas Kedokteran Universitas Pelita Harapan (FK UPH), ditemukan berbagai situasi pembelajaran yang mempengaruhi mahasiswa dalam memilih pendekatan belajar. Mahasiswa mengidentifikasi: a) beban belajar yang terlalu padat; b) materi terlalu banyak sehingga mahasiswa harus memilih yang dipelajari dan yang tidak; c) penyampaian kuliah yang tidak menarik; d) persepsi tentang assessment yang hanya membutuhkan hafalan untuk lulus; e) kriteria penilaian yang kurang jelas; $\mathrm{f})$ kuliah yang tidak efektif; g) ketiadaan arah yang jelas tentang tujuan belajar, dan $\mathrm{h}$ ) penjadwalan yang tidak merata mengarahkan mereka untuk belajar secara sekilas. Di sisi lain a) penjelasan yang disertai contoh nyata kasus; b) dosen yang interaktif; c) dosen yang mampu menjelaskan; d) dosen yang memberikan feedback yang spesifik; e) adanya kemandirian belajar, dan $\mathrm{f}$ ) tujuan belajar yang jelas memacu mahasiswa untuk belajar lebih mendalam.

Blok muskuloskeletal dipilih untuk diteliti karena beberapa alasan. Alasan utamanya adalah adanya persepsi mahasiswa yang buruk terhadap situasi pembelajaran serta didukung dengan data nilai blok muskuloskeletal yang cenderung semakin buruk jika dibandingkan dengan blok lainnya. Blok muskuloskeletal merupakan blok yang pertama dari rangkaian blok sistem organ yang dialami mahasiswa FK UPH. Blok dengan pendekatan sistem organ merupakan metode utama selama proses pendidikan sarjana kedokteran. Oleh karena itu, penting mengetahui situasi pembelajaran yang terjadi di blok muskuloskeletal serta kaitannya dengan pendekatan belajar yang diterapkan mahasiswa.

Blok Muskuloskeletal berlangsung selama lima minggu. Pada awal blok, mahasiswa diberi buku blok yang berisi learning objectives yang harus dicapai selama blok berlangsung untuk memberikan arahan serta tujuan belajar yang jelas kepada mahasiswa. Metode pembelajaran yang diterapkan adalah diskusi tutorial, kuliah tatap muka, dan praktikum. Diskusi kelompok tutorial berlangsung tiga kali dalam satu minggu dengan durasi dua jam setiap pertemuannya, membahas satu kasus pemicu dengan dibimbing seorang tutor. Masalah yang digunakan dalam diskusi kelompok, membantu mendorong mahasiswa untuk bekerja dalam tim dan berpikir kritis dalam menganalisis masalah. Kuliah diberikan secara interaktif antara 6-8 jam per minggunya, dan topik yang diberikan adalah topik penting yang belum dibahas dalam tutorial. Praktikum dilaksanakan dengan mengintegrasikan berbagai disiplin ilmu pada blok muskuloskeletal tersebut serta mengkaitkan dengan 
tema yang sedang dipelajari. Di antara kegiatan terstruktur tersebut, mahasiswa juga diberi waktu untuk belajar secara mandiri. Pada belajar mandiri mahasiswa diberi keleluasaan menentukan tema belajar sesuai dengan kebutuhan masing-masing. Pada akhir blok mahasiswa akan diuji dengan ujian pilihan ganda. Butir soal yang digunakan berupa vignette yang mendorong mahasiswa ke arah pengertian bukan hafalan. Butir tersebut telah di-review sebelumnya yang disusun berdasarkan learning objectives.

Berbagai komponen situasi pembelajaran yang mempengaruhi terbentuknya pendekatan mendalam yaitu: pengajaran yang baik, tujuan yang jelas, kemandirian dalam belajar, serta umpan balik yang diberikan tepat waktu; sementara pendekatan dangkal dikaitkan dengan persepsi beban kerja yang terlalu tinggi, assessment yang cenderung hafalan. ${ }^{4,5}$

Ramsden yang disitasi Watkins ${ }^{5}$ menyatakan bahwa meningkatkan kesadaran mahasiswa tentang pendekatan belajar yang diterapkan, merupakan bagian integral dari proses belajar mengajar. Fakultas harus mengidentifikasi bagaimana pendekatan mahasiswa diperlukan. Pemahaman tentang pendekatan belajar merupakan hal penting karena untuk dapat mengubah pendekatan belajar mahasiswa diperlukan mengubah pengalaman, persepsi, dan konsepsi belajar mahasiswa. Karena itu penting mengidentifikasi komponen situasi pembelajaran yang mempengaruhi pendekatan belajar mahasiswa.

\section{TUJUAN}

Tujuan penelitian ini adalah mengetahui persepsi mahasiswa terhadap situasi pembelajaran dan pendekatan belajar mahasiswa; serta mengetahui pengaruh persepsi mahasiswa blok muskuloskeletal FK UPH terhadap situasi pembelajaran dengan pendekatan belajar yang diterapkan.

\section{METODE}

Penelitian ini adalah penelitian dengan metode campuran (mixed method) yang terdiri dari penelitian kuantitatif dan kualitatif. Kombinasi metode ini dilakukan dengan pendekatan kuantitatif sebagai pendekatan utama (dominant), serta pendekatan kualitatif sebagai fasilitator (less dominant) yang memberikan interpretasi dan klarifikasi terhadap hasil penelitian kuantitatif. Subjek penelitian kuantitatif adalah seluruh mahasiswa yang sedang mengikuti blok muskuloskeletal di FK UPH. Subjek penelitian kualitatif ditentukan dengan metode purposive sampling berdasarkan data pendekatan belajar pada penelitian kuantitatif. Metode wawancara mendalam digunakan untuk menelusuri gambaran pola hubungan antara persepsi situasi pembelajaran dengan pendekatan belajar yang diterapkan. Seluruh subjek yang terlibat telah menandatangani lembar persetujuan untuk ikut serta dalam penelitian.

Cara pengumpulan data dengan instrumen persepsi situasi pembelajaran Course Experience Questionnaire (CEQ) yang dikembangkan Ainsley dan Long ${ }^{6}$ dan instrumen pendekatan belajar Revised Study Process Questionnaire 2 Factors (R-SPQ-2F) yang dikembangkan Biggs et al. ${ }^{7}$ Kedua kuisoner telah diterjemahkan oleh ahli bahasa dan konteks isi butir-butirnya telah dikonsultasikan ke ahli pendidikan kedokteran. Lalu kuesioner persepsi situasi pembelajaran diujicobakan kepada 56 mahasiswa memberikan hasil Cronbach alfa $=0,794$ dan untuk validitas ditemukan 2 butir pertanyaan yang nilai $r<$ 0.3; butir lalu diperbaiki dan diikutsertakan kembali. Pada ujicoba kuesioner pendekatan belajar ditemukan seluruh butir memiliki $r>0,3$, dan ditemukan nilai Cronbach alfa 0,643. Maka seluruh butir dapat diikutsertakan dalam penelitian. Pada fase kualitatif wawancara mendalam dilakukan peneliti dengan menggunakan pedoman wawancara sebagai panduan yang disusun berdasarkan komponen-komponen situasi pembelajaran yang mempengaruhi pendekatan belajar.

Teknik analisis data kuantitatif yang digunakan pada penelitian ini adalah analisis statistik deskriptif dan analisis statistik inferensial. Uji statistik yang dipakai adalah uji korelasi Spearman. Sedangkan untuk menganalisis kekuatan pengaruh komponen situasi pembelajaran terhadap pendekatan belajar akan dihitung dengan odds ratio. Analisis data kualitatif yang dipergunakan adalah analisis konten (content analysis) yang meliputi proses identifikasi, pengkodean dan kategorisasi data. 


\section{HASIL}

Pengumpulan data penelitian kuantitatif dilakukan dengan menyebarkan kuesioner kepada 106 mahasiswa Blok Muskuloskeletal FK UPH. Uji kesahihan dan kehandalan terhadap kedua instrumen penelitian yaitu: Cronbach Alfa sebesar 0,810 dan 0,614. Validitas untuk butir-butir dalam instrumen yang dipakai secara keseluruhan memiliki nilai $r>0,3$, dengan rentang nilai 0,402 sampai dengan 0,825 , dengan nilai $\mathrm{p}<0,05$. Sugiyono $^{8}$ menyatakan suatu instrumen dikatakan sahih apabila memiliki $r>0,3$. Sementara Cohen, et. al. ${ }^{9}$ memberikan batasan nilai kehandalan 0,6 sebagai nilai yang dapat diterima. Merujuk pada kedua literatur tersebut, maka dapat disimpulkan bahwa instrumen yang dipakai merupakan instrumen yang sahih dan handal.

\section{Deskripsi Data Hasil Penelitian}

Berdasarkan skor tertinggi dan terendah yang dapat diperoleh dari nilai kuesioner, maka persepsi situasi pembelajaran dikategorisasikan secara normatif menjadi 2 tingkatan, yaitu kurang baik dan baik seperti yang ditampilkan pada Tabel 1.

Tabel 1. Distribusi frekuensi mahasiswa berdasarkan persepsi situasi pembelajaran

\begin{tabular}{llccc}
\multicolumn{1}{c}{$\begin{array}{c}\text { Persepsi situasi } \\
\text { pemblajan }\end{array}$} & Kategori & $\begin{array}{c}\text { Batasan } \\
\text { nilai }\end{array}$ & $\begin{array}{c}\text { Jumlah } \\
\text { mahasiswa }\end{array}$ & $\begin{array}{c}\text { Persentase } \\
(\%)\end{array}$ \\
\multirow{2}{*}{ Kualitas pengajaran } & Kurang baik & $5-15$ & 24 & 22,64 \\
& Baik & $16-25$ & 82 & 77,36 \\
\hline \multirow{2}{*}{ Kejelasan assessment } & Kurang baik & $3-9$ & 73 & 68,87 \\
& Baik & $10-15$ & 33 & 31,13 \\
\hline \multirow{2}{*}{ Kesesuaian beban belajar } & Kurang baik & $6-18$ & 78 & 73,58 \\
& Baik & $9-30$ & 28 & 26,42 \\
\hline \multirow{2}{*}{ Kejelasan tujuan belajar } & Kurang baik & $3-9$ & 43 & 40,57 \\
& Baik & $10-15$ & 63 & 59,43 \\
\hline \multirow{2}{*}{ Kcmampuan bclajar yang } & Kurang baik & $7-21$ & 12 & 11,32 \\
diperoleh & Baik & $22-35$ & 94 & 88,68 \\
\hline
\end{tabular}

Pendekatan belajar yang diterapkan dikategorisasikan secara normatif dapat dilihat pada Tabel 2.

Tabel 2. Distribusi mahasiswa berdasarkan pendekatan belajar yang diterapkan

\begin{tabular}{lccc}
\multicolumn{1}{c}{ Pendekatan belajar } & $\begin{array}{c}\text { Batasan } \\
\text { nilai }\end{array}$ & $\begin{array}{c}\text { Jumlah } \\
\text { mahasiswa }\end{array}$ & Persentase (\%) \\
\hline Pendckatan dangkal & $-40-0$ & 11 & 10,38 \\
Pendekatan dalam & $1-40$ & 95 & 89,62 \\
\hline
\end{tabular}

Hipotesis penelitian ini adalah persepsi terhadap situasi pembelajaran berhubungan dengan pendekatan belajar. Adanya persepsi situasi pembelajaran yang baik akan mendukung pendekatan belajar mendalam. Untuk menguji hipotesis ini maka dihitung nilai korelasi dan odds ratio (OR) dari masing-masing persepsi terhadap komponen situasi pembelajaran. (Tabel 3). 
Tabel 3. Rekapitulasi nilai $\mathrm{r}$ dan oods ratio persepsi komponen situasi pembelajaran terhadap pendekatan belajar mahasiswa

\begin{tabular}{lcccc}
\multicolumn{1}{c}{ Persepsi Situasi Pembelajaran } & $\begin{array}{c}\text { Spearman's } \\
\text { rho }\end{array}$ & $\begin{array}{c}\text { Odds } \\
\text { Ratio }\end{array}$ & $\begin{array}{c}\text { 95\% Confidence } \\
\text { Interval }\end{array}$ & p-value \\
\hline Persepsi kualitas pengajaran & 0,17 & 3,33 & 14,54 & 0,71 \\
Persepsi kejelasan assessment & 0,13 & 1,23 & 7,69 & 0,27 \\
$\begin{array}{l}\text { Pcrscpsi kcscsuaian bcban } \\
\text { belajar }\end{array}$ & 0,25 & 1,69 & 17,078 & 0,32 \\
$\begin{array}{l}\text { Persepsi kejelasan tujuan belajar } \\
\text { Persepsi kemampuan belajar }\end{array}$ & 0,26 & 1,88 & 8,34 & 0,44 \\
\hline
\end{tabular}

Pada hasil uji hipotesis ini didapatkan nilai korelasi dan odds ratio pada masing-masing komponen situasi pembelajaran tidak memiliki nilai yang signifikan secara statistik $(p>0,05)$. Dengan demikian, dapat disimpulkan bahwa tidak terdapat hubungan bermakna antara persepsi mahasiswa terhadap situasi pembelajaran dengan pendekatan belajar yang diterapkan di blok muskuloskeletal.

\section{PEMBAHASAN}

Hasil analisis data kuantitatif penelitian ini menunjukkan bahwa persepsi terhadap situasi pembelajaran yang terdiri dari pengajaran, kejelasan assessment, kejelasan tujuan belajar, kesesuaian beban belajar, dan kemampuan belajar yang diperoleh tidak memiliki hubungan yang signifikan secara statistik ( $p$ value $>0,05$ ) dengan pendekatan belajar yang diterapkan mahasiswa. Hal ini berarti bahwa variabel persepsi situasi pembelajaran tidak dapat dipakai sebagai prediktor pendekatan belajar yang akan diterapkan mahasiswa. Temuan ini berbeda dengan hasil yang ditemukan pada penelitian Lizzio ${ }^{10}$ dan Parpala, et al. ${ }^{11}$ Parpala et al. ${ }^{11}$ menemukan bahwa mahasiswa yang memiliki persept si yang baik terhadap situasi pembelajaran menerapkan pendekatan mendalam, sementara mahasiswa yang memiliki persepsi yang kurang baik terhadap situasi pembelajaran, menerapkan pendekatan dangkal. Hal serupa dikemukakan Lizzio ${ }^{10}$, khususnya pada komponen pengajaran yang interaktif mengarahkan pada pendekatan dalam, sementara persepsi buruk terhadap assessment dan beban belajar mengarahkan pada pendekatan dangkal.

Tidak ditemukannya hubungan bermakna antara persepsi mahasiswa terhadap situasi pembelajaran dengan pendekatan belajar yang diterapkan pada fase kuantitatif penelitian ini dikarenakan terdapat berbagai faktor lain yang mempengaruhi penerapan pendekatan belajar. Hal ini didukung oleh Sambell, McDowell, dan Brown yang dikutip Baeten et al. ${ }^{12}$ yang menyatakan bahwa kurangnya motivasi internal, pada suatu situasi pembelajaran yang baik sekalipun, akan menghambat mahasiswa untuk menerapkan pendekatan belajar mendalam. Baetten et al. ${ }^{12}$ mengemukakan beberapa faktor internal yang mempengaruhi penerapan pendekatan belajar $\mathrm{di}$ antaranya: pendekatan belajar sebelumnya, kebiasaan belajar, karakteristik kepribadian, selfesteem, dan rasa takut untuk gagal.

Mahasiswa, dalam hal pendekatan dalam, memandang suatu proses pengajaran sebagai proses yang memberikan pengertian dan bukan hanya sekedar penyampaian berbagai data dan informasi:

"...dosen harus ngasih sesuatu yang lebih mudah ditangkap. Misalkan bukan hanya membaca..."

Proses tutorial yang dialami dipersepsikan sebagai proses yang mengarahkan pada belajar mendalam dan melihat peran tutor yang besar dalam membantu mengarahkan pembelajaran:

"Kalau tutor...dia menyuruh kita supaya lebih kritis... Jadi disuruh ngambil dari buku-buku..."

Informasi ini mengkonfirmasi temuan deskriptif pada penelitian kuantitatif yang menyatakan terdapat persepsi yang cukup baik terhadap pengajaran khususnya berkaitan dengan tutor. Hal ini terbukti pada kuesioner butir 13 ('Tutor di sini biasanya memberi umpan balik yang berguna tentang kinerja saya'), butir 18 (Tutor benarbenar berusaha untuk memahami mahasiswa yang mengalami kesulitan dalam mengerjakan pekerjaan mereka'), butir 19 ('Tutor mendedikasikan banyak waktu 
untuk mengkomentari kinerja mahasiswa'). Pada ketiga butir tersebut, mahasiswa menyatakan setuju dan sangat setuju yaitu secara berturut-turut sebesar $42,5 \& 20,8$; $36,8 \& 17,0 ; 26,4 \& 11,3 \%$. Hal ini menunjukkan bahwa sebagian besar mahasiswa memiliki persepsi yang baik terhadap kualitas pengajaran khususnya tutor. Dapat dikatakan pula bahwa tutor berperan penting dalam membantu mahasiswa untuk menentukan pembelajaran yang akan dilaksanakan.

Pengajaran dipersepsikan baik oleh mahasiswa:

“...Karena dosen menjelaskan apa yang perlu dijelaskan...Kalau tutor... selalu mendorong kita untuk mencari. Jadi mau nggak man kita harus cari terus".

Dosen juga mengarahkan pada pendekatan mendalam dalam belajar:

"Justru saya jadi, mau nggak mau harus belajar terus. Kalau tidak, saya akan tertinggal."

Hal ini sesuai dengan yang dikemukan Watkins ${ }^{5}$, Diseth $^{13}$, yang menemukan bahwa persepsi terhadap pengajaran yang baik akan mengarahkan mahasiswa untuk pendekatan dalam.

Namun, dari mahasiswa dengan pendekatan mendalam pun diperoleh informasi bahwa terdapat situasi pembelajaran yang kurang baik:

“...Dosennya tidak memberikan yang tidak normal itu dengan ciri-ciri apa saja yang perlu kita lihat dalam preparat ini. Jadi, pandangan untuk pelajaran ini jadi abstrak."

Hal ini membuat mahasiswa pendekatan mendalam kehilangan motivasi sehingga menerapkan pendekatan dangkal pada materi tersebut, seperti yang dikutip berikut ini:

"Saya jadi tidak termotivasi. Saya jadi memprioritaskan pelajaran itu jadi yang terakhir....Khusus bagian ini saya jadiin prioritas terakhir".

Mahasiswa yang menerapkan pendekatan dangkal mengidentifikasikan bahwa tutor yang kurang mampu mengarahkan membuat mahasiswa tidak mempelajari suatu tema secara mendalam.

“...kalau tutornya pasif, pesertanya jadi tidak terdorong untuk menggali lebih dalam lagi."
Cara pembawaan kuliah yang terlalu datar serta minim interaksi juga membuat mahasiswa kehilangan semangat untuk memperhatikan materi yang diberikan:

"Kalau di kelas, kadang monoton...."

Dalam penerapan pendekatan belajar, mahasiswa mengkombinasikan penerapan pendekatan dalam dan dangkal. ${ }^{12} \mathrm{Hal}$ ini menjelaskan latar belakang ditemukannya pendekatan dangkal yang diterapkan oleh mahasiswa pendekatan mendalam pada penelitian ini.

Sebagian besar mahasiswa mempersepsikan beban belajar yang berat. Hal ini tampak khususnya pada kuesioner butir 1 ('Beban belajar pada blok ini terlalu berat') dan 24 ('Banyaknya volume beban belajar yang harus dikerjakan pada blok ini membuat anda tidak dapat mengerti blok ini dengan seksama.'). Pada kedua butir ini mayoritas mahasiswa menjawab setuju dan sangat setuju secara berurut sebesar 34,9\% \& 15,1\%; $33,0 \% \& 15,1 \%$. Pada butir 24 tidak ditemukan mahasiswa yang sangat tidak setuju; bahkan pada butir 1 tidak ditemukan mahasiswa yang menjawab tidak setuju atau sangat tidak setuju. Hal ini menunjukkan bahwa pada sampel ini memiliki persepsi yang relatif homogen terhadap beban belajar. Hal ini didukung temuan persepsi beban belajar yang kurang baik pada $73,58 \%$ responden.

Lebih lanjut lewat wawancara mendalam diperoleh bahwa beban belajar dipersepsikan berlebih oleh mahasiswa pendekatan dangkal

"...mungkin karena banyak tugas segala macam, ...Tugasnya masih banyak, jadi konsentrasi di lecture juga nggak bisa 100\%."

“...dikasih deadline yang terlalu cepat, sama bahan yang terlalu banyak...Karena kita kan ngerjainnya harus cepat dan juga banyak. Waktunya juga singkat. Jadi kita cuma nyalin doang."

Hal ini didukung literatur yang menyatakan bahwa beban belajar yang dipersepsikan berlebihan akan mengarahkan mahasiswa untuk menerapkan pendekatan dangkal ${ }^{4,10}$ Sivirko dan Mellanby yang dikutip Baetten ${ }^{12}$ juga menemukan bahwa mahasiswa akan cenderung mengambil jalan pintas dan menerapkan pendekatan dangkal pada situasi beban belajar yang dipersepsikan berlebihan. 
Hal senada diungkapkan juga oleh mahasiswa pendekatan mendalam:

“... belajar blok muskuloskeletal agak terburu-buru, jadi maksudnya bahannya itu banyak tetapi waktunya cuma seminggu"

"... padahal itu kan banyak tapi cuma dikasih waktu seminggu...."

Meskipun sama-sama mempersepsikan keterbatasan waktu, antara kedua pernyataan di atas terdapat latar belakang yang berbeda. Pada mahasiswa pendekatan dangkal beban belajar yang kurang baik mempengaruhi tingkat perhatian terhadap proses pengajaran, sementara pada mahasiswa pendekatan mendalam, banyaknya beban yang diberikan menghambat mahasiswa untuk mempelajari tema secara lebih mendalam.

Mahasiswa mempersiapkan asesmen berdasarkan pengalaman yang diperoleh sebelumnya. Jika suatu asesmen dipersepsikan hanya membutuhkan reproduksi detail mengenai fakta, maka mahasiswa akan menerapkan pendekatan dangkal yang hanya melibatkan proses kognitif sederhana seperti menghafal. Sementara, apabila asesmen dipersepsikan sebagai proses kognitif yang lebih tinggi yang memerlukan pengertian yang menyeluruh, maka mahasiswa akan menerapkan pendekatan mendalam. ${ }^{14}$ Karena pengalaman yang diperoleh cukup beragam, maka pendekatan yang dilakukan juga berbedabeda. Pada sampel penelitian ini khususnya pada kuesioner butir 17 ('Soal ujian blok akan lebih menekankan pada hafalan daripada pemahaman'); ditemukan lebih banyak mahasiswa yang setuju dan sangat setuju (32,2\%) dibandingkan dengan mahasiswa yang sangat tidak setuju dan tidak setuju $(30,1 \%)$. Pada mahasiswa yang memperkirakan asesmen yang akan dihadapi adalah berupa pengertian maupun ilustrasi kasus, mahasiswa dengan pendekatan mendalam, mengkaitkan asesmen yang dihadapi dengan manfaat yang akan diperoleh di masa yang akan datang:

"... banyak pengertian. Soalnya kalau kita cuma menghafal, tidak bisa aplikasi ya, apa gunanya di pekerjaan kita."

Hal ini didukung temuan Gulikers, Kester, Krischner, dan Bastaens yang disitasi Baetten ${ }^{12}$ bahwa mahasiswa yang mempersepsikan asesmen mereka sebagai hal yang mewakili kehidupan profesional mereka kelak, akan menerapkan pendekatan mendalam.
Mahasiswa pendekatan dangkal menghadapi asesmen dengan fokus berusaha untuk menghafalkan sebanyakbanyaknya:

"... Kalau misalnya ada nama-nama aneh, harus dihafalin juga."

"Hafalan, fixed banget hafalan....Ya, menghafal. Memaksa buat hafalin.... lebih ke maksa sih.... Ya, mau nggak mau maksa sendiri untuk hafal."

Sementara, mahasiswa yang mengantisipasi bahwa asesmen yang akan dihadapi akan berupa hafalan, meskipun pada dasarnya mahasiswa tersebut adalah mahasiswa yang cenderung melakukan pendekatan mendalam, mahasiswa tersebut akan mencoba untuk menghafalkan sedikit demi sedikit:

“...saya berusaha mengangsur untuk setiap minggu. Materi dari setiap minggu saya pelajari kembali melalui PBL, membuat LO..."

Mahasiswa pendekatan mendalam juga dapat beradaptasi dan menyempitkan cakupan belajarnya apabila asesmen yang dihadapi berupa hafalan:

"Saya rasa sih, pasti banyak hafalan.... Belajar sesuai dengan apa yang ada di block book."

Hal ini dikonfirmasi Iphofen yang disitasi Seale, Chapman dan Davey ${ }^{15}$ bahwa adanya interpretasi yang didasari pada pengalaman terdahulu dapat mempengaruhi pendekatan belajar yang diterapkan.

Ramsden ${ }^{1}$ menyatakan bahwa standar dan tujuan yang jelas penting dalam pembelajaran yang baik. Dari sampel penelitian ini, persepsi tentang kejelasan tujuan belajar khususnya pada butir 9 ('Anda biasanya mempunyai gagasan yang jelas tentang tujuan anda dan apa yang diharapkan pada blok ini') ditemukan mahasiswa yang setuju dan sangat setuju sebesar $46,2 \%$ dan $8,5 \%$ sementara yang sangat tidak setuju dan tidak setuju sebesar 0,9\% dan 3,8\%. Hal ini secara garis besar menunjukkan bahwa tujuan belajar dalam blok muskuloskeletal ini jelas.

Pada pembelajaran di blok muskuloskeletal yang menerapkan PBL, mahasiswa merumuskan sendiri pembelajaran mereka lewat learning objective yang diperoleh. Nijhuis, Segers dan Gijselaers (2005) menyatakan bahwa pembelajaran PBL memang 
memberikan kebebasan kepada mahasiswa untuk menentukan pembelajaran sendiri; namun di sisi lain hal ini dapat menimbulkan ketidakpastian akan relevansi dari hal yang dipelajari. Hal ini mungkin yang menjelaskan adanya temuan lain berupa ketidakjelasan tujuan belajar secara keseluruhan sebesar 40,57\% pada mahasiswa di blok muskuloskeletal.

Pada wawancara mendalam dengan mahasiswa pendekatan dalam mempersepsikan tujuan belajar yang cukup jelas dalam blok muskuloskeletal yang sedang dijalankan:

"...Dari block book, itu kan ada LO-nya, learning objective yang perlu kita pelajari apa saja."

Namun adanya tujuan belajar yang dicantumkan dalam buku blok, bagi mahasiswa pendekatan dangkal dirasakan kurang memadai, seperti yang diungkapkan informan berikut:

"Saya sih tidak diberi tuntunan.... cuma saya agak bingung, mau belajarnya mulai dari mana...Jadi ya...ya sudahlah..."

Dapat diamati bahwa hal ini makin mengarahkan mahasiswa untuk belajar secara sekilas dan melakukan pendekatan dangkal.

Ketidakjelasan manfaat yang diperoleh ditambah dengan jumlahnya yang banyak membuat mahasiswa tidak mempelajari suatu hal secara mendalam:

"... tugasnya banyak dan rata-rata nggak penting. Jadi kita waktu untuk fokus ke pelajaran itu jadi lebih kurang."

Hal ini menjelaskan bahwa pada mahasiswa dengan pendekatan dalam pun pada situasi yang tidak mengarahkan pada pendekatan mendalam, dapat menerapkan pendekatan dangkal. Namun dari kuesioner diperoleh bahwa pada butir manfaat belajar, khususnya pada butir 11 ('Sebagai hasil dari blok ini, saya mampu menghadapi masalah-masalah baru') dan 12 ('Blok ini menajamkan keterampilan analisis saya') didapatkan nilai setuju dan sangat setuju cukup besar, secara urut adalah $46,2 \%$ \& 3,8\%; 54,7\% \& 6,6\%. Temuan ini didukung hasil wawancara dengan informan yang menyatakan:

"Kan kebetulan Oma juga Osteoartritis... Nggak ngerti kan..... Setelah itu belajar, jadi mengerti ternyata si Oma itu sakitnya ini."
"Yang paling bermanfaat sih waktu,...tentang sport injury kita bisa tahu, pengaplikasian cedera waktu melakukan aktivitas sport."

Manfaat kemampuan yang diperoleh untuk jangka panjang dalam kaitan sebagai profesi sebagai dokter juga tampak pada kutipan yang diucapkan informan:

"Karena, sebagai dokter umum, kalau misalnya nanti kita kerja di Unit Gawat Darurat, pasti kejadian accident itu berhubungan sama MSK, bisa ketabrak, bisa jatuh."

Kalimat di atas mengkonfirmasi temuan pada penelitian kuantitatif bahwa sebagian besar mahasiswa memperoleh manfaat khususnya dalam kemampuan menganalisis dan memecahkan masalah-masalah baru.

Motivasi internal dalam belajar mencakup keyakinan pribadi akan kemampuan diri seseorang untuk mampu melaksanakan suatu tugas, alasan keterlibatan, pengetahuan terdahulu tentang suatu materi, kebiasaan, dan reaksi afektif terkait suatu kegiatan pembelajaran. Menurut Slavin yang disitasi Baharuddin \& Wahyuni ${ }^{16}$ motivasi adalah proses dalam diri individu yang mendorong, menjaga, dan memberikan arahan. Semua hal ini turut mempengaruhi pendekatan belajar yang diterapkan mahasiswa.

Mahasiswa yang telah terbiasa mempelajari suatu hal secara mendalam, meskipun dihadapkan pada situasi yang mengarahkan pada pendekatan dangkal, akan tetap berusaha menerapkan pendekatan mendalam, seperti yang diungkapkan informan berikut ini:

"...Jadi lebih ke arah dimengerti bukan dihafal. Saya memang dari dulu belajarnya jarang menghafal, lebih dimengerti."

Situasi pembelajaran, seberpengaruh apapun hanyalah merupakan salah satu faktor yang mempengaruhi proses pendekatan belajar yang kompleks. Vermunt yang disitasi Papinzak et al. ${ }^{17}$ menyebutkan bahwa kebiasaan belajar terdahulu dapat menjadi faktor internal yang mempengaruhi cara mahasiswa belajar saat ini. Hal ini menegaskan bahwa selain situasi pembelajaran, terdapat motivasi internal yang dapat mengarahkan penerapan pendekatan mendalam.

Di sisi lain, motivasi internal ini dapat pula memberikan pengaruh yang mengarahkan pada pendekatan dangkal: 
"Untuk mempelajari lebih dalam, tidak. Saya hanya mempelajari apa yang perlu dipelajari. Saya tidak berminat sekali..."

Di sini tampak bahwa meskipun cenderung melakukan pembelajaran mendalam, mahasiswa ini tidak memiliki ketertarikan terhadap tema yang dipelajari. Pendekatan mendalam yang diterapkan lebih dikarenakan memenuhi tuntutan kewajiban untuk belajar.

Adanya faktor internal berupa selfesteem yang ditemukan pada mahasiswa pendekatan dalam, memotivasi mahasiswa untuk lebih mendalam mempelajari suatu tema, seperti yang diungkapkan informan berikut:

"Itu jadi pemicu sih. Kenapa sih orang-orang pada tahu..."

“...Kalau kita tidak tahu apa-apa, jadinya malu sendiri...Jadi kan buat pemicu."

Sobra ${ }^{18}$ menemukan pada studinya terhadap mahasiswa kedokteran bahwa terdapat faktor motivasi internal dan motivasi eksternal yang mempengaruhi cara pendekatan belajar mahasiswa. Dalam hal ini motivasi internal memiliki peranan yang lebih penting. Sobral pada penelitiannya terhadap 247 mahasiswa kedokteran semester tiga Universitas Brasilia menemukan korelasi positif antara motivasi internal dengan pendekatan mendalam. Hal ini menegaskan pentingnya peran motivasi internal dalam penerapan pendekatan belajar.

Faktor ketertarikan terhadap suatu materi memegang peranan penting dalam menentukan pendekatan apa yang akan dilakukan. Pada mahasiswa pendekatan dangkal, rasa ketidaktertarikan cukup dominan ditemukan pada beberapa informan di antaranya:

“...saya kurang suka cuma saya menikmati sih sekarang... Nggak sih. Karena saya tidak terlalu suka dengan yang terlalu spesifik dalam tulang."

Pada mahasiswa yang secara dominan melakukan pendekatan mendalam pun, jika tidak memiliki rasa ketertarikan, maka mahasiswa akan menerapkan pendekatan dangkal. Hal ini dapat dilihat dari pernyataan berikut:

"...saya tidak terlalu tertarik untuk belajar di dalam ini. Saya kurang berminat ke bagian ini."

Setelah ditelusuri hal ini berdampak pada pendekatan belajar yang diterapkan:
"Untuk mempelajari lebih dalam, tidak. Saya hanya mempelajari apa yang perlu dipelajari. Saya tidak berminat sekali untuk lebih dalam."

Lebih lanjut adanya persepsi yang terbentuk pada pembelajaran terdahulu yang mengarahkan pada pendekatan dangkal, semakin mengarahkan mahasiswa ke pendekatan dangkal:

“...kita juga sudah dilatih untuk menghafal otototot dari tubuh. Sehingga di sini kita hanya tinggal mengingat saja,tidak perlu kita menghafal lagi dari nol kembali."

Dari pernyataan di atas tampak jelas adanya interaksi antara motivasi internal yang kurang pada tema muskuloskeletal dengan pengalaman belajar pendekatan dangkal pada blok sebelumnya yang mengarahkan mahasiswa untuk kembali menerapkan pendekatan dangkal dalam blok muskuloskeletal. Hal ini sesuai dengan hukum Law-effect yang menyatakan bahwa apabila suatu tindakan diikuti dengan perubahan yang memuaskan, maka tindakan akan kembali dilakukan dan akan terus meningkat secara kualitas; dan sebaliknya. ${ }^{16}$

Keterpaparan sebelumnya terhadap materi yang akan dipelajari membantu mahasiswa untuk lebih mudah memahami hal yang akan dipelajari. Pengetahuan ini memberikan gambaran garis besar konsep sehingga menimbulkan motivasi dari dalam diri mahasiswa untuk mempelajari suatu tema. Hal ini diungkapkan informan sebagai berikut:

"Dulu SMA sih, pernah belajar anatomi tulang dan klasifikasi tulang itu. Jadi ada kayak gambaran sedikit-sedikit."

Karena mahasiswa tidak memasuki suatu situasi pembelajaran dalam keadaan kosong, melainkan dipengaruhi oleh pengalaman dan pengetahuan sebelumnya, maka pengetahuan terdahulu tersebut turut mempengaruhi pendekatan mahasiswa terhadap blok muskuloskeletal yang sedang dihadapi. Hal ini didukung temuan Beckwith yang disitasi Baetten et al. ${ }^{12}$ bahwa pengetahuan sebelumnya berbanding terbalik dengan penerapan pendekatan dangkal. Pada penelitian ini peneliti menemukan bahwa mahasiswa melalui pengetahuan sebelumnya maupun yang diperoleh dari blok sebelumnya di fakultas kedokteran, membantu mahasiswa mendapat gambaran umum tentang blok 
yang akan dipelajari sehingga mahasiswa lebih tertarik terhadap blok muskuloskeletal.

Dari wawancara mendalam juga diidentifikasikan berbagai hal yang melatari ketertarikan mahasiswa terhadap blok muskuloskeletal:

"Rasa penasaran saya saja berubah setiap masuk ke kasus..."

Sedangkan hal yang mendasari ketidaktertarikan mahasiswa adalah:

"Saya biasa saja,bukan suatu passion yang gimana banget. Kemudian untuk prakteknya, untuk orthopedik itu kan butuh tenaga yang besar, misalnya tarik tulang. Jadi, saya pikir untuk saya kurang pas."

"...Blok muskuloskeletal ini kan hafalannya harus benar-benar kuat....saya ini kurang jago kalau suruh ngafalin."

Adanya pengaruh rasa keingintahuan ini didukung oleh temuan Baetten ${ }^{12}$ bahwa adanya rasa keingintahuan yang mendalam tentang suatu hal mengarahkan pada penerapan pendekatan mendalam. Baetten et al..$^{12}$ juga menegaskan bahwa adanya ketertarikan terhadap suatu materi akan mengarahkan pada pendekatan mendalam. Sementara jika mahasiswa tidak tertarik dengan blok yang dihadapi maka mahasiswa akan cenderung menerapkan pendekatan dangkal. Seale, Chapman dan Davey ${ }^{15}$ juga mengungkapkan hal serupa bahwa adanya ketertarikan akan mendorong mahasiswa untuk menerapkan pendekatan belajar mendalam.

Temuan pada penelitian ini juga sesuai dengan yang ditemukan Mann dalam Sobral ${ }^{18}$ yang menyatakan bahwa pada mahasiswa kedokteran, adanya motivasi yang beragam dapat menghasilkan pendekatan belajar yang berbeda, meskipun telah dikondisikan dalam situasi pembelajaran yang mengarahkan pada pendekatan dalam.

Berdasarkan uraian di atas, dapat disimpulkan bahwa terdapat berbagai faktor motivasi internal yang berperan dalam pembelajaran mahasiswa. Bersama-sama dengan persepsi situasi pembelajaran, motivasi internal saling berinteraksi mempengaruhi pendekatan belajar yang diterapkan mahasiswa di blok muskuloskeletal.

\section{KESIMPULAN}

Dari hasil penelitian dan pembahasan yang telah dilakukan, dapat disimpulkan beberapa hal sebagai berikut:
1. Sebagian besar mahasiswa memiliki persepsi yang baik terhadap kualitas pengajaran, kejelasan tujuan belajar, kemampuan belajar yang diperoleh di blok muskuloskeletal.

2. Mahasiswa cenderung memiliki persepsi yang kurang baik terhadap kejelasan assessment dan kesesuaian beban belajar.

3. Pada blok muskuloskeletal mahasiswa lebih cenderung menerapkan pendekatan belajar mendalam.

4. Tidak terdapat hubungan yang signifikan secara statistik antara persepsi mahasiswa terhadap situasi pembelajaran dengan pendekatan belajar yang diterapkan.

5. Motivasi internal seperti ketertarikan terhadap materi, pengetahuan sebelumnya, serta self-esteem, turut mempengaruhi pendekatan belajar yang diterapkan mahasiswa.

\section{SARAN}

Berdasarkan hasil temuan pada penelitian ini institusi pendidikan, khususnya blok koordinator muskuloskeletal disarankan untuk melakukan peninjauan ulang terhadap situasi pembelajaran di blok muskuloskeletal dengan menerapkan kasus-kasus pemicu yang kontekstual, sehingga lebih mengarahkan mahasiswa pada pendekatan mendalam. Kasus pemicu yang dikembang-kan adalah yang lebih mengarah pada kejadian yang ditemui mahasiswa sehari-hari. Jadwal di dalam blok muskuloskeletal juga perlu disesuaikan, sehingga memberikan waktu yang lebih bagi mahasiswa untuk belajar mandiri agar mampu lebih memahami materi dengan menerapkan pendekatan belajar mendalam. Perlu diteliti lebih lanjut mengenai motivasi internal yang belum menjadi fokus utama dalam pada penelitian ini untuk mengetahui dengan lebih jelas perannya terhadap pendekatan belajar yang diterapkan mahasiswa.

\section{DAFTAR PUSTAKA}

1. Ramsden P. Learning to teach in higher education. New York: Routledge Falmer; 2006.

2. Mattick K, Dennis I, \& Bligh J. Approach to learning and studying in medical student: validation of a revised inventory and its relation to student characteristic and performance. Med. Educ. 2004;38:535-43. 
3. Emilia O. Students' approach to learning. Jurnal Pendidikan Kedokteran dan Profesi Kesehatan Indonesia. 2006;1(3):61-8.

4. Cope C, Staehr L. Improving students' learning approaches through intervention in an information system learning environtment. Studies in Higher Educ. 2005;30(2):181-97.

5. Watkins D. Factors influencing the study methods of Australian tertiary students. Higher Educ. 1982;11:369-80.

6. Ansley J, Long M. The course experience survey 1992 graduates. Canberra: Australian Government Publishing Services; 1994.

7. Biggs J, Kember D, Leung YP. The revised two factor study process questionnaire: R-SPQ-2F. Brit. J. of Educ. Psychology. 2001;71:133-49.

8. Sugiyono. Metode penelitian kualitatif, kuantitatif dan R\&D. Bandung: Alfabet; 2010.

9. Cohen L, Manion L, Morrison K. Research method in education. London: Routledge; 2007; p.501-542.

10. Lizzio A, Wilson K, Simons R. University student perception of the learning environment and academic outcome: implication for theory and practice. Studies in Higner Educ. 2002; 27(1): 27-54.

11. Parpala A, Ylane SL, Komulainen L, Litmanen T, Hirsto L. Students' approach to learning and their expiriences of teaching learning environment. Brit. J. of Educ. Psychology. 2010; 80:269-82.

12. Baeten M, Kyndt E, Struyven K, Dochy F. Using student centered learning environment to stimulate deep approach to learning: factors encouraging or discouraging their effectiveness. Educ. Research Review. 2010;5: 243-60.

13. Diseth A, Martinsen O. Approach to learning, cognitive style, and motives as predictors of academic achievement. Educ. Psychology. 2003;23(2):195-209.

14. Gijbels D, Segers M, Struyf E. Constructivist learning environment and the (im)possibility to change students' perception of assessment demands and approach to learning. Instr. Sci. 2008;36: 431-43.

15. Seale JK, Chapman J, Davey C. The influence of assessments on students' motivation to leran in therapy degree course. Med. Educ. 2000; 34:614-21.

16. Baharuddin, Wahyuni EN. Teori belajar dan pembelajaran. Yogyakarta: Arruz Media; 2010.

17. Papinczak T, Youn L, Groves M, Haynes M. Effects of metacognitive intervention to students' approach tolearning and self-effecacy in first year medical course. Advances in Health Sci. Educ. 2008;13: 213-32.

18. Sobral DT. What kind of motivation drives medical students' learning quest?. Med. Educ. 2004;38: 950-7. 